Patron-Client Politics, Democracy and Governance in Nigeria, 1999-2007 


\title{
Patron-Client Politics, Democracy and Governance in Nigeria, 1999-2007
}

\author{
Oarhe Osumah \\ Department of Public Administration \\ Ambrose Alli University \\ Ekpoma - Nigeria \\ Email:Osumahoarhe@Yahoo.Com
}

\begin{abstract}
This paper examines patron-client politics in the context of democracy and governance in Nigeria with special focus on the first phase of the Fourth Republic, 1999-2007. The paper, which is essentially based on study of secondary source of data, revealed that the politics is neither historically new nor peculiar to Nigeria. Its evidence abounds in older democracies, emerging democracies and even authoritarian regimes. In Nigeria, its evidence abounds in the pre-colonial political system through the colonial era to the previous civil administrations in the country since independence. The paper revealed that pecuniary motivation and the deployment of primitive tactics to settle political scores make the patron-client politics a unique phenomenon in the recent political history of the country. The paper further reveals that the contemporary practices of patron-client politics negate the fundamental values and principle of democracy and governance. The plausible explanation adduced for the influx and changes in the patron-client politics include structural character of the Nigerian state which creates large stakes for the control of state power and other factors such as political decay, weak party structure and discipline, imperial presidency, political immaturity and lack of political charisma among office seekers.
\end{abstract}

Keywords: Patron, Client, Democracy, and Governance

\section{INTRODUCTION}

Since the last decade of the $20^{\text {th }}$ century a new wave for democratic change has been blowing across the continents of the world. Nigeria alongside with many countries in Africa has embraced the wind of change from authoritarian rule to democratic rule. The military assumed the historic mission of establishing, nurturing and sustaining democracy and good governance. The maiden attempt at democratic change but became aborted through the 
annulment of the June 121993 presidential election presumably won by Chief M.K.O. Abiola was under the General Ibrahim Babangida administration. The political heat generated by the annulment compelled the Babangida administration to step aside and cede power to an Interim National Government headed by Chief Ernest Shonekan. The Interim National Government, which lacked legitimacy, was sacked on November 17, 1993 by military junta led by General Sani Abacha. Thus, the nation was returned to military rule. From 1993 the Abacha administration initiated a transition to democratic rule but could not complete it before the demise of Abacha on June 8, 1998. Again, the transition to democratic rule was restarted under Abacha's successor, General Abubakar Abdusalam. The Abdusalam administration successfully ended the tortuous journey to the popularly preferred but seemingly elusive democracy in Nigeria with the inauguration of the Fourth Republic on May 29, 1999.

Since the birth of the Fourth Republic 1999, the phenomenon of political patron-client politics has been particularly pervasive in the politics and governance of Nigeria. In fact, any objective analysis of politics and governance in Nigeria in the Fourth Republic must as a matter of necessity include the role and activities of the political patrons and their clients. The pervasive impact of the phenomenon of the patron-client politics in a single discourse such as this cannot be given a comprehensive treatment that it requires. The objective of this paper therefore is to demonstrate the extent to which the phenomenon opposes the fundamental values and principles of democracy and governance in Nigeria with special focus on the Fourth Republic, 1999-2007. Before we proceed to address the central issue of the paper it is imperative to begin with the examination of the central concepts, patron-clients, democracy and governance.

\section{Conceptual Notes}

Patron-client in the Nigerian political parlance denotes godfatherism, which essentially conceived as a personalized relationship between actors or group of actors wielding asymmetrical affluence, status or power, based on qualified loyalties and concerning political dealings (Lemarchand 1972: 69). This conception has two perspectives, traditional and contemporary (Onwuzuruigbo not dated, Folarin 2005:37). In the traditional perspective political patron is essentially an experienced statesman expected to mentor, guide, direct and counsel upcoming politicians on how to engage in political activities such as campaign and contest for election in civilized and constitutional manner as well as manage the affairs of the state for the realization of common good if given the opportunity to serve. A political patron is a person with history, derivation and purebred. In the traditional sense, political patrons exert power and influence not for personal but group interest. Thus, the political patron is a benevolent, an altruistic, development oriented, and missionary and not mercenary politician. The patrons offer leadership, ideas, expertise, knowledge and wisdom to their clients. The 
relation they maintain with their political client is mutually beneficial and based on commonality of interest (Odivwri not dated). The activities of the political patron are, ideological, civilized and constitutional. The activities are intended to ensure the affairs of the state are managed in a manner that promotes necessary development in the interest of the ordinary man (Folarin 2005:37). The traditional concept of patron-client focuses on the enthronement of the principles and values of democracy and governance. It intended to arm or equip the political client with necessary expertise for management of the affairs of the state to ensure growth, stability and common welfare.

The contemporary conception can be regarded as a redefinition, distortion and transformation of the traditional conception. It perceived the political patron as a "mercenary politician" ready to offer sponsorship to office-seekers to the extent the individual accepts to be manipulated for the consolidation of his power-base and sustenance of his political dominance of the affairs of the state. Instructively, the power of the patron does not merely lay in his sponsorship of political campaigns. Largely, the power and influence stems from the ability to deploy primitive tactics, patronizing political violence, silencing of political opponents, electoral fraud and manipulation of state machinery in favour of the client. In reciprocation, the patron expect to largely determine how to run the government he helped enthrone by exerting pressure on the client not on how to formulate and execute people- and development-oriented policies but to siphon state resources for the extension and consolidation of his political influence and control. The patron deploys various forms of political weapons such as propaganda, blackmail, thuggery, hooliganism, kidnapping, threat and political assassinations or other silent means in order to ensure the continued influence and control over the client and the machinery of the state (Folarin 2005:37). The patron-client connection in the contemporary era smacks criminality, malevolence, oppression, selfishness, self-serving and parasitism (Obia 2004:c6). In some instances, political patrons are officials in government who deploy the resources and instrument of the political community in favour of their clients.

Pithily, the patron-clients relations have been characterized as follows. First, the patron-client relation is rooted on strong inequality and power differences. "The central party structure controls economic, political and technical resources" as well as determines the organization of the state structure and its operations (Chaine 2007:355-384). Second, the relation may involve reciprocal collaboration and not entirely one-way affair. The exchange transactioa differs from one context to another in terms of accruing benefits, status, protection and authority. However, accruing benefits in the transaction exchange especially in respect to the client is based on loyalty and obedience. Third, the strength of the patron-clients transaction is essentially a function of the distributive capacity at the central level. Quite often, disagreement and dissatisfaction in relationship between the patrons and their clients is occasioned by asymmetrical distribution of resources. 
Thus, the patron-client relations "retain its homeostatic qualities" when the distribution of benefits is mutually satisfying and not lopsided (Chaine 2007: 355-384). As Chaine (2007: 355-384) noted conflicts among patrons are not ideological, but are disagreements over control of state resources, authority to influence key positions in the party and government structure, and the ability to gain enough followers to win office. Finally, elections, with or without the deployment of any means provide the ground for the consolidation of powerbase and sustenance of political dominance of sharing the characteristics of political machine for the governance of the affairs of the state. Voting support by groups is "the mechanism to meet demands for goods and services for constituencies" (Chaine 2007: 355-384).

Democracy is another concept central to this discourse. It is a very popular concept in the literature particularly of political science that yet has no generalized definition. It is defined variously to suit contextual usage. Thus, in the context of this discourse, democracy can be defined as a form of government and philosophy based on active participation of the largest possible number of citizens and intended to promote common good of every member of the political community. It is neither merely a government which exists for itself nor merely set of assumptions of the organization of government. It is a set of thought and a mode of action propelled by common welfare and directed by a large majority of the adult members of the political community. It is neither the ascendancy of self-serving interest nor unrestrained accumulation of public funds for personal aggrandizement of a select few smart thugs (Ehusani 2002:10)

Another aspect of democracy is that it entails the idea of constitutional supremacy. It is a government guided by laws and not the whimsicality of men. Furthermore, democracy emphasizes compromise in the face of diverse and desperate opinions. Also fundamentally essential about democracy is the active popular participation in the political process in terms of voting and representation in government by qualified persons vide free, fair and credible election. Still, democracy is about freedom and protection of personal liberties, as well as affirmation and promotion of equality in politics and governance.

Governance is an imprecise concept. Its meaning and processes are difficult to specify. Nonetheless, it is essentially synonymous with good government and sound development management. It is concerned with the management of the affairs of a state according to the organic or supreme law of the land. It is governing based on constitutional provisions and statutory law rather than the whims and caprices of individual or groups. It encompasses the process of recruiting, monitoring and changing government as well as the formulation of sound policies for the fulfillment of common welfare. Governance is also expected to provide the mechanisms, processes and institutions for citizens and groups to articulate their interest, exercise their rights, meet their obligations and mediate their differences (Pryor 2003; B4). In sum, the qualities of governance depend on the promotion and realization of common welfare and respect for citizens. It entails essentials 
attributes such as an efficient public service, an independent judicial system and legal framework to enforce contracts, transparency, the accountability of administration of public funds, compliance with due process, prudent management, popular participation, control of rulers through electoral process, effective separation of powers, decentralization of power, assurance of adequate and responsible representation in relevant institutions, and assurance of legitimacy in the conduct of rulers.

Governance signifies the employment of both legitimacy and authority derived from democratic mandate and normally entails a pluralist polity with responsible representative government and commitment to promotion of common welfare. The fundamental objectives of good governance and democracy are the championing of ethical behaviour in business transactions and promotion of greater transparency and accountability. These fundamental objectives are realizable when political contest is rooted in civilized and constitutional conduct such that will bring about necessary development in the interest of the citizenry.

In the traditional conception, political-client connection can be supportive in the building of democracy and promotion of the values of good governance as it repudiates arbitrariness, extremism, oppression, crass opportunism, insensitivity, irresponsibility, arrogance and corruption. The connection can engender systematic application of rules in the recruitment of political leadership and management of the affairs of the state for the fulfillment of common welfare. Indeed the philosophy of the patron-client in the traditional sense was driven by the desire to perpetrate democratic style and values of governance. However, when the patron-client connection assumes negate transformation as it is in the contemporary politics in Nigeria, it becomes dysfunctional to the interest of the whole.

\section{Patron-Client Politics and the Nexus of Mercenary in Nigeria}

Patron-client politics is not historically new in Nigeria. In Nigeria, the phenomenon of patron-client politics predates the advent of colonialism. Evidence of patron-client relation abounds in the traditional political systems of Igbo, Yoruba and Hausa/Fulani. In the traditional political system, political patrons played several roles ranging from settlement of disputes to provision of training in the art of warfare, politics and administration to their client. In reciprocation for such services, their client pay tributes, taxes, respect and pledge allegiance (Nnamani 2007, Onwuzuruigbo not dated). Clearly, the patron-client relation in the pre-colonial era was symbiotic and mutually beneficial. Thus, the relation was hardly disruptive to the process of politics and development. Following the introduction of colonial rule, the traditional patron-client politics was integrated into the colonial system of administration through indirect rule. However, during the period of colonial rule, the patrons were merely turn instruments for the administration of law and order in the fulfillment of the exploitative mission of the colonialists. In 
the course of time these patrons were gradual pushed to the background with the emergence of the educated elites.

By the 1950s when active party politics began a new set of patrons emerged. At independence, the politicians of old such as Alhaji Ahamedu Bello, Chief Obafemi Awolowo, Aihaji Aminu Kano and Dr. Nnamdi Azikwe became the political patrons. Respectively they were patrons of Alhaji Tafawa Balewa, Lateef Jankande, Alhaji Balarabe Musa, and Jim Nwobodo. Only in few cases were deep rifts generated between the patrons and their clients as a result of the struggle for the sharing of state resources. A famous example of patron-client politics with pecuniary undertone in the First Republic was the struggle between Azikwe and Eyo Ita of the NCNC. The Sir Strafford FosterSutton Commission of Inquiry revealed the former had attempted to get the latter to lodge local government fund in the Africa Continental Bank where his relation were shareholders (Odion 2007). Similarly, in the Second Republic only a few cases of rifts between patrons and clients were recorded. A classic reference was, in Kwara state Chief Olusola Saraki helped installed Governor Adam Attah. However, before the 1983 general election they had serious disagreement over sharing of state resource, which cost Attah his reelection. Sarki supported the candidacy of the opposition UPN, late Josiah Olawoyin. Instructively, the patron-client phenomenon with pecuniary motivation in the First and Second Republics had not gained so much ascendancy (Odion 2007).

The patron-client politics with pecuniary nexus particularly underwent rapid changes during the military administration of General Ibrahim Babangida. These changes came as a result of the move by the administration to rid the political turf of old breed politicians whose political activities were believed to be detrimental to the promotion of good governance. The administration introduced the politics of newbreedism, which further galvanized the upsurge of corruption, entrenched interest and moneybagism in politics (Isekhure, 1992:25). As soon as the ban on politics was lifted for the transition to the Third Republic Isekhure (1992: 17\&50) noted that "certain categories of Nigerians who themselves constituted persona-nongrata to the politics and collapse of the previous republics were desperately looking for associations to buy..." Others sponsored delegates to participate in conventions of some associations while the activities of certain individuals contaminated and hijacked "the formation of the political parties from their infancy through the avenue of money to install themselves in power..." "The group solidarity was mortgage for personal reward and propensity to make quick money and unholy alliance". This laid the fertile ground for reinforcement of patron-client politics with commercial undertone.

\section{Profile of Patron-client Politics in the From 1999 to 2007}

Since the exit of the military from governance and with the enthronement of civil rule in 1999, the patron-client politics with strong commercial alliance 
and networks witnessed a re-emergence, mushroomed and become a permanent presence in the country's political turf. Evidence of patron-client political phenomenon abounds at various levels of government and in many of the dominant political parties in the federation. The phenomenon of patron-client politics is also practiced at the senatorial districts, federal constituencies, local government and ward levels. In a non-exhaustive search of literature the table below shows some of the states where patron-client politics has been a seemingly permanent presence.

\begin{tabular}{|c|c|c|c|c|}
\hline S/No & Date & State & Patron-client & Forms of Relation \\
\hline 1 & $\begin{array}{l}1999- \\
2003\end{array}$ & Kwara & $\begin{array}{l}\text { Chief } \text { Olusola Saraki } \\
\text { Vs } \quad \text { Governor } \\
\text { Mohammed Lawal }\end{array}$ & $\begin{array}{l}\text { Strained, involved deployment of violence, and } \\
\text { eventually resulted in the deposition of Lawal in } \\
2003 \text { poll }\end{array}$ \\
\hline 2 & $\begin{array}{l}1999- \\
2003\end{array}$ & Enugu & $\begin{array}{ll}\text { Chief Jim Nwobodo } \\
\text { Vs } & \text { Governor } \\
\text { Chimaroke } & \end{array}$ & Strained \\
\hline 3 & $\begin{array}{l}1999- \\
2003\end{array}$ & Anambra & $\begin{array}{l}\text { Chief Emeka Offor Vs } \\
\text { Governor Chinwoke } \\
\text { Mbadinuju }\end{array}$ & $\begin{array}{l}\text { Strained, involved the deployment of violence and } \\
\text { dropping of Mbadinuju in } 2003 \text { poll due to } \\
\text { performance failure }\end{array}$ \\
\hline 4 & $\begin{array}{l}1999- \\
2003\end{array}$ & Bornu & $\begin{array}{lr}\text { Modi Sherif } & \text { Vs } \\
\text { Governor } & \text { Mala } \\
\text { Kachalla } & \end{array}$ & $\begin{array}{l}\text { Strained, Modi deposed Kachalla in the } 2003 \text { poll to } \\
\text { become the governor }\end{array}$ \\
\hline 5 & $\begin{array}{l}1999- \\
2003\end{array}$ & Kano & $\begin{array}{l}\text { Alhaji Abubakar Rimi } \\
\text { Vs Governor Rabiu } \\
\text { Kwankwaso }\end{array}$ & Strained \\
\hline 6 & $\begin{array}{l}1999- \\
2007\end{array}$ & Edo & $\begin{array}{l}\text { Chief Anthony Anenih } \\
\text { Vs Governor Lucky } \\
\text { Igbenedion }\end{array}$ & $\begin{array}{l}\text { Warmed but later turned cold after Anenih single- } \\
\text { handedly endorsed Igbinedion for the } 2003 \text { poll. } \\
\text { Involved recrimination, accusations and counter- } \\
\text { accusations }\end{array}$ \\
\hline 7 & $\begin{array}{l}2003- \\
2007\end{array}$ & Oyo & $\begin{array}{l}\text { Alhaji Lamidi Adedibu } \\
\text { Vs Governor Rasheed } \\
\text { Ladoja }\end{array}$ & $\begin{array}{l}\text { Strained and involved the deployment of violence, } \\
\text { impeachment of Ladoja but later reinstated by the } \\
\text { court }\end{array}$ \\
\hline 8 & $\begin{array}{l}2003- \\
2005\end{array}$ & Anambra & $\begin{array}{l}\text { Chief Chris Uba Vs } \\
\text { Governor Chris Ngige }\end{array}$ & $\begin{array}{l}\text { Strained and involved the deployment of violence, } \\
\text { police abduction and deposition of Ngige through the } \\
\text { court ruling based on the confession of election fraud } \\
\text { by Uba }\end{array}$ \\
\hline 9 & 20032007 & Osun & $\begin{array}{l}\text { Chief S.M. Afolabi Vs } \\
\text { Governor Olagunsoye } \\
\text { Oyinlola }\end{array}$ & Warmed \\
\hline 10 & $\begin{array}{l}2003- \\
2007\end{array}$ & Benue & $\begin{array}{l}\text { Chief Barnabas } \\
\text { Germade Vs Governor } \\
\text { George Akume }\end{array}$ & $\begin{array}{l}\text { Strained and resulted in the sack of Germades } \\
\text { political loyalties from the state executive council. }\end{array}$ \\
\hline 11 & $\begin{array}{l}1999- \\
2003\end{array}$ & Adamawa & $\begin{array}{l}\text { Alhaji Atiku Abubakar } \\
\text { Vs Governor Bonu } \\
\text { Haruna }\end{array}$ & $\begin{array}{l}\text { Warmed and resulted in the re-election of Haruna in } \\
2003 \text { poll }\end{array}$ \\
\hline
\end{tabular}

Source: Compiled by the author from various Nigerian Newspapers

Instructively, the table above only showed some representative cases of patron-client connections between political godfathers and state governors. The relations between the acclaimed patrons and their clients have largely been crisis-ridden characterized by disagreements, antagonism, accusation and counter- accusations, blackmail, bizarre manipulation of party and state machineries, uncanny and weird manipulation of electoral process with aid of thugs, threat and actual deployment of violence and brigandage to secure and consolidate political advantage. The major sources of most of these crises are the sharing of public funds, political patronage and personality cult. The patrons usually desire to secure absolute loyalty, political patronage in terms of appointments of key political officeholders, award of contracts and 
enjoyment of a large share of the financial allocation to the state from the clients. Notably, it is only in few states such as Lagos, Osun and Adamawa that there was a semblance of sanity. These were states in which the patrons (godfathers) have not been overbearing (Williams 2009:7 Emphasis Mine).

The phenomenon of patron-client politic is not peculiar to Nigeria. It is a global phenomenon. Evidence of patron-client abounds in older democracies, emerging democracies and even authoritarian regimes. Several countries where strong patron-client connection exists include Mexico and Kenya in the 1980s and 1990s (Grindle 1996), Bangladesh (Kochanek 1993), the Soviet Union in the post-revolutionary period (Ackerman 1999), the Sicilian mafia in Italy patronize and sponsor candidate for elective positions and in return get compensation in the form of patronage (Gambetta 1993), America in the pre-world war II era (Odion 2007:75), in South Africa in the postapartheid regime (Folarin 2005). Other democracies where patron-client politics has evolved are Australia and Bolivia. Instructively, the patron-client politics in most of the old and emerging democracies has positive value of accountability, citizenship consciousness and equality. In most of these countries, the citizens have avenue to supplant a party that fails to perform up to their expectations with a rival party (Philp 2001, Lazar 2004, Omobowale and Olutayo 2007: 425-446). Also in those societies, those who want to belong to any of the dominant party have equal chance of joining the party and being given the post they are qualified. Neither the godfathers nor moneybags are allowed under any guise to dictate to others as far as the policies are concerned. Thus, their politics are able to prop up the best candidates for public offices and governance (Daniel 2008:64). In Nigeria, the patron-client relation is based on master servant relation and motivated by commercial interest at the detriment of public interest. The patrons foist charlatans or hooligans on the rest of the people and help to ensure that they stay in office for as long as they desire. The clients in return device perfidious schemes aimed at boosting the residual interest of the cabal (Daniel 2008:64).

\section{Implications of Contemporary Patron-Client Politics for Democracy and Governance in Nigeria}

Although the phenomenon of patron-client politics is not peculiar to Nigeria, the dimension it assumes seem quite unique and uncommon and antithetical to democratic growth and survival. Democratic principles involve among other things free and fair elections, constitutionalism, the right of majority to choose leaders and mandate them to make decisions and perform functions aimed at realizing common good. The contemporary notion of patron client politics negates such principles. Elections are said to be free and fair when devoid of electoral malpractices. According to Folarin (2003:37) the political patrons in contemporary Nigeria educates the political clients "to engage in perfidious and treacherous acts in winning elections - gaining the mandate of the people, silencing oppositions, patronizing, purchasing and lobbying 
stakeholders, orientation on looting". In Nigeria's Fourth republic the patronclient politics resulted in the brazen manipulation of state machinery in the process of political recruitment in favour of preferred candidates of the patrons. For example, Chris Uba openly confessed in the court how he masterminded the rigging of the Anambra state governorship election held in 2003 in favour of erstwhile governor Chris Ngige. While it may be difficult to ascertain the veracity of his claim but the subsequent annulment of the election and declaration of Peter Obi as the legitimately elected governor by the court tells the tale of how the electorate have been shut out from democratic interaction and limitedness of their ultima ratio of power due to patron-client political relation in the contemporary times.

Furthermore, the contemporary increasing dysfunctional patron-client politics stifles electoral contests, as the patrons are willing to do anything to frustrate and neutralize opposition from securing seats in government in order to get maximum return for their investment. Although political violence is not historically new in Nigerian political contest, the swift from the traditional weapons such as accusation and counter accusations and use of light weapons to huge deployment of sophisticated guns and the establishment and use of armed gangs is new and unique development. The heightened political violence and extremism that characterized the general elections held in 2003 and 2007 are rooted in the dysfunctional patron-client politics. In fact, the July 10, 2003 political gangsterism against Governor Ngige in Anambra state with the aid of police led by AIG Raphael Ige is clearly a new development in the patron-client relation in Nigerian politics.

The pervasiveness and increasing dysfunctional of contemporary patronclient politics heats up politics and governance through the show of brinkmanship. The various political weapons they deploy explain this. They deploy political weapons such as propaganda, thuggery, hooliganism, kidnapping, abduction, blackmail, threat, and political murder against their clients when they renege on agreement. A case of the extremism of the patron-client politics is exemplified in the July 10, 2003 political gangsterism against Governor Ngige in Anambra state with the aid of police led by AIG Raphael Ige.

Another consequence of the contemporary practice of patron-client politics is that it negates the principles of accountability, prudent management and common good, which is a vital to both democracy and governance. It lays the foundation for the privatization, ransacking and personalization of public funds and failure to utilize state resources to meet the genuine and legitimate needs of the people. The patrons offer their clients assistance as capital investment to which they expect high returns. This orients the political clients to looting, corruption and sleaze in the management of the affairs of the state at the expense of the electorate. In fact, it can be asserted that the pervading underdevelopment, collapse of infrastructure and service, socio-economic deprivation, anxiety and insecurity have been more acute in the states where the patron-client politics became a major feature. An instance may suffice. In Anambra state, crisis of 
development and governance under governor Mbadinuju manifested in owing of civil servants and teachers several months of salary. The situation resulted strike action by the civil servants and teachers in the state. It also generated critical comments and agitations by the civil society. The Anambra state chapter of the Nigerian Bar Association was very critical of the sordid state of affairs during this period. This cost the lives of the state chapter of the association, Barnabas Igwe, and his wife who were murdered by suspected political assassins (Uwehejewe-Togbolo 2005).

The dysfunctional patron-client politics in the recent times increased the cost of governance. The crisis, power play, intrigues, bad blood, antagonism between the patrons and their clients cost a lot of fortunes in terms of waste of state resources, disruption of government business. The destruction and burning of government properties in Anambra state is a case in point. Besides, the patron-client relation led the constitution of top-heavy executive councils in most states with not less than $50 \%$ of the appointments as protégés of the patrons. In the face of political acrimonies between the patrons and their clients, these nominees of usually take side with the patrons. They in fact often initiate and superintend projects aimed at embarrassing and frustrating the clients. An instance may suffice to justify this assertion. Governor Gabriel Suswan of Benue State blamed some members of his executive for several non-performing projects. These nonperforming members of the executives are loyalties of his godfather, Senator George Akume, the immediate past governor of the state. It is only in few instances the clients are able to muster the political will to sack such nonperforming nominees of the patrons (Nwakaudu 2009:73).

The pervasiveness and increasing dysfunctional patron-client politics spawn catastrophic consequences on the institutions such as the political party, police, legislature especially the state legislative assemblies and the judiciary that are required to strength democratic growth and effective governance. Political party is a critical element of democracy. It is in fact the political machine for nurturing democratic growth. Patron-client political relation fuels intra-party squabbles and wrangling as well as political crises in the steering of the affairs of a state. In most states, there was the establishment of parallel party secretariats and proliferation of party officials at the ward, local government and state levels. More so, the dysfunctional patron-client politics was essentially a symptom and a major cause of the factionalization and conflict between the executive and legislature that permeated the process of governance in the country. Legislature-executive conflict is not a recent development in politics and governance in Nigeria. However, the parliamentary irresponsibility and rascality in the greater part of the period between 2003 and 2007 several states which crystallized into unwarranted change of leadership in the state assemblies in Anambra, Oyo, Plateau, Edo and Delta and impeachment of the chief executives were function of the dysfunctional patron-client politics. The dysfunctional patronclient relation also resulted in the use of the police as instrument for achieving self-serving end. A case in point is the July 10, 2003 police 
involvement in the coup political gangsterism against Governor Ngige in Anambra state. The a team of police personnel led by AIG Raphael Ige was said to have acted on the script of Chris Uba without consultation with the Inspector General of the Police to abduct Governor Ngige.

Also, the kind of structure, social norms, mindset and cosmologies developed in the patron-client relation that has prevailed under Obasanjo presidency is capable of discouraging people suffused in the interests, problems, and needs from indicating interest or vying for elective positions. Given the instruments and extremism involved in the patron-client political relations in the first phase of the Fourth Republic people of integrity are abound to steer clear from politics and governance. This may rob the nation of patriotic leadership and allows for the enthronement of a larger number of mediocre, treasury looters and kleptomanias. Thus far in the current dispensation, the management, wastefulness, licentiousness, parsimoniousness and squanderism of state resources could be adduced to lack of credible and responsible representatives in government.

\section{Explanatory Notes}

The pervasive and increasing dysfunctional patron-client politics since 1999 is not an independent phenomenon. Several explanations, some structural and others behavioural can be constructed for the nature patron-client politics. To recapitulate the patron-client politics because of the commercial nexus during this period was characterized by destructive intense violence, brinkmanship, gangsterism, illegality, maliciousness, accusations and counter-accusations, intimidation of opposition candidates to gain unfair advantage, abuse of office, corruption and failure to dispense democratic dividends to the people. At the root of these tendencies and deployment of crude and primitive tactics in the contest for political office is the structural character of the state. As Claude Ake (1996:7) observed much of what is uniquely negative about politics in Africa arise from the character of the state, particularly its lack of autonomy, immensity of its power, its proneness to abuse, and lack of autonomy and lack of immunity against it. The character of the state rules out a politics of moderation and mandates a politics of lawlessness and extremism for the simple reason that the nature of the state makes the capture of state power irresistibly attractive

The structural character of the Nigerian state creates high premium for state power and so much reliance on the state for access to the good things of life. In Nigeria, political office offers the possibility of ransacking the public treasury for the benefit of a select few. As Larry Diamond posits power has replaced effort as the basis for social reward. The net result of the high premium of the state power as the quickest gateway to accumulation, progress and cheap popularity conditions political profiteering, investment of huge capital for political campaign with the anticipation to plough back the invested capital as well as turnover. It also encourages the deployment of 
primitive tactics in the face of disagreement or renegement in negotiated terms in order to secure for capital investment and selfish interest

The Nigerian state is extremely authoritarian and repressive in nature. Governance of the state is seemingly a privatized and personalized rule. It revolves round the personality cult of the chief executives at various levels of government. The state hardly keeps faith with the constitution. It is not guided by the norms of democracy such as negotiation, consultation, accommodation and compromise. By its nature, vast majority are politically powerless and sidelined from the mainstream of political activities. It lacks commitment to democracy, nullifies democratic processes and enthrones the regimes of the privileged few (Ojo 1996)

These distinctive character and tendencies of the Nigerian state creates an enabling environment for commercial alliance and network such as patron-client connection in the process of political recruitment, acquisition and control of state power. The game of politics attracts the investment of the moneybags and patrons because the state serves as the surest avenue to accumulation of wealth and actualization of fame.

Furthermore, the weakness and ineffectiveness of party structure and lack of party discipline contributed to the influx and change in the patronclient politics. The prolong military dominance of politics have murdered the development of political ethos, party system, structures and discipline and matured and charismatic politicians required for true democratic interactions. Studies have suggested that attitudes are conditioned by regimes and historical experiences and political socialization As Larry Diamond (not dated) noted the cognitive, attitudinal and evaluation dimensions of political culture are to regime performance, historical experience and political socialization. The primitive and uncivilized political tactics and weapons that have characterized the patron-client relations in the first phase of the Fourth Republic admirably reflect the level of political amateurish and pre-maturity as well as undigested orientation of democratic values and conduct perhaps due to long years of military rule.

Other factors, which can be ascribed for the growth of pecuniary motivated patron-client politics between 1999 and 2007, included imperial presidency, political decay and corruption.

\section{CONCLUSION}

Recent history and development of patron-client politics with mercenary nexus in Nigeria have been a growing concern. Nigeria is familiar with isolated cases in the past; the current democratic order enthroned in 1999 has awakened the reality of highly organized dimension of patron-client politics with pecuniary motivation. It involves the huge deployment of primitive tactics in the face of disagreement. As a result the development of the nascent 
democracy has been exposed to ominous dangerous threats. The personalized rule, privatization of state resources, deployment or adoption of primitive tactics, lack of accountability and exclusion of the civil society or vast majority in mainstream of politics coupled with insensitivity to common welfare nullify the democratic possibility and effective governance. Several factors have been identified as plausible cause for growth of the pecuniary motivated patron-client politics since 1999. These include structural character of the Nigerian state which creates large stakes for the control of state power and other factors such as political decay, weak party structure and discipline, imperial presidency, political immaturity and lack of political charisma among office seekers. Thus, it is the position of this author that it is only in the context of a reconstructed and legitimate state and re-orientations of the political actors to the minimum values of democratic governance that the pervasive and increasing destructive dysfunctional practice of patron-client politics in recent times that our nascent democracy can be consolidated and the problems of effective governance frontally resolved

\section{REFERENCES}

Ackerman, S.A (1999). Corruption in Government: Causes, Consequences and Reforms, USA: Cambridge University Press

Ake, C. (1996). "The Political Question", in: O. Oyediran (ed), Governance and Development in Nigeria, Ibadan: Agbo Areo Publishers

Chaine, P. (2007). "Clientelism and Ethiopia's Post 1991 Decentralization", Journal of Modern African Studies, Cambridge University Press, pp.355-384

Daniel, Soni (2008). "Muffled applause for a tower of Babel", The Punch, Thursday, December 11

Diamond, L. (Not Dated). "Nigeria Pluralism, Statism and Struggle for Democracy" in L. Diamond, J.J. Jinz and S.M Lipset (eds) Democracy in Developing Countries (Africa), vol. II Boulder in Colrado: Lynne Poienne Publishers

Ehusani, George (2002). "Politics of Acrimony and Greed", This Day, Friday, August 9

Grindle, M.S (1996), Challenging the Crisis and Innovation in Latin America and Africa, Cambridge University Press

Isekhure, Nosakhare (1992). Democracy in Crisis: Edo State Tribunal in Perspective, Benin City: Jodah Publications

Hyden, G. (1999). "Governance and Reconstitution of Political Order" in: Richard

Joseph (ed.) State, Conflict and Democracy in Africa, Boulder: Lynne Rienner Publishers, pp. 179-195

Kochaneck, S.A. (1993). Patron-client Politics and Business in Bangladesh, New Delhi: Sage Publications 
Lazar, S.(2004). "Personalist Politics, Clientelism: Structure, Process And Optic, In: Bulletin Of Latin American Research 23, 2 pp 228-43

Lemarchand, R. (1972). Political Clientelism and Ethnicity in Tropical Africa: Competing Solidarities in Nation Building, American Political Science Review, vol. V1, pp. 68-90

Nnamani, C. (2007). "Godfatherism and Nigerian Democracy", The Constitution, vol.7, No. 2, June

Nwakauda, Simeon (2009). "Akume / Suswam: Associates Fuel Conflict", The Guardian, Sunday, June 28

Obia, Vincent (2004). 'Godfather are Political Criminals, says Falana”, Daily Independent, Monday, February 16

Odion, W.E. (2007). 'Godfatherism in Nigerian Politics: Implications for Development" The Constitution, vol.7, No. 2, June

Odivwri, Eddy (Not Dated). "Governors, their Godfathers", This Day Online

Ojo, S.O.J. (1995). "Alternative Critiques of Student Unrest in Nigeria" in : F.E Iyoha, B.U. Chizea, S.A. Akpotor (eds.), Self-Reliance, Politics and Administration in Nigeria, Benin City: Imprint Services pp

Omobowale, Ayokunle Olumuyiwa and Olutayo Akinpelu Olanrewaju (2007). "Chief Lamidi Adedibu and Patronage Politics in Nigeria", Journal of Modern African Studies, Cambridge University Press, 45, 3

Onwuzuruigbo, Ifeanyi (Not Dated). "Two Conception of Godfatherism and Party Politics in Nigeria", Department of Sociology, University of Port Harcourt

Philp, M. (2001). "Access, Accountability and Authority: Corruption and Democratic Process", Crime, Law and Social Change, 36,4

Uwhejevwe-Togbolo, Samuel (2005). “ Politicians and Political Godfatherism" Friday, April 22

Williams, Alabi (2009). Power Game: Godsons Step On Toes Of Godfathers", The Guardian, Sunday, June 28 